\title{
An Investigation of Professors' Views on Membership in Professional Organizations
}

D. Donald Kent, Fr., Phyllis Bloom, and Susan L. Murphy

D. Donald Kent, Jr. is Associate Professor of Accounting, The College at Brock. Phyllis Bloom is Associate Professor of Accounting Nazareth College. Susan L. Murphy is Professor of Accounting Monroe Community College

\begin{abstract}
This study examines how college accounting educators in New York State view membership in accounting professional organizations and what influences their decisions not to join. Based on an on-line survey, we find that accounting educators generally agree that belonging to and participating in accounting professional organizations is important. They tend to be neutral regarding statements about benefits outweighing the costs of membership and that organizations such as the AICPA and the NYSSCPA have lost their significance for accounting educators. In giving the main reason for not being a member of the NYSSCPA, respondents most often indicated cost of dues and that the organization did not meet their needs.
\end{abstract}

Keywords: professional organizations, membership, NYSSCPA 


\section{INTRODUCTION}

Professionals have traditionally grouped together into organizations related to their vocation or profession. A profession is defined as a "calling requiring specialized knowledge and often long and intense academic preparation” (Merriam-Webster's Collegiate Dictionary, 2001, p. 928). A professional is described as one who is "engaged in one of the learned professions" and "characterized by or conforming to the technical or ethical standards of a profession” (ibid.).

Professional organizations provide many benefits to their members including opportunities for networking, exchanging ideas, and promoting their careers (McWeeny, 2008; Devohish-Mills, 2008; Scarborough, 2008; Schea, 2009). Recently, the American Accounting Association (AAA) launched its social networking site AAACommons (King and Sutherland, 2008). Professional organizations can also help in times of economic downturns (Schea, 2009). Committed to the advancement of professional excellence, these organizations provide the following benefits to its members:

- Advocating to regulators and the public regarding issues facing the profession

- Development and enforcement of a code of professional conduct

- Enhancing the image of the profession to the public

- Providing educational seminars for $\mathrm{CPE}$

- Providing opportunities to engaging in community service

- Providing educational outreach to young people interested in accounting

Professional accounting organizations have existed for many years. The American Institute of Certified Public Accountants (AICPA) was founded in 1887 as the American Association of Public Accountants (Previts and Marino, 1998). The New York State Society of Certified Public Accountants was created in 1897 while the Institute of Management Accountants and the Institute of Internal Auditors were established 
in 1919 and 1941, respectively (NYSSCPA, 2009; IIA, 2009; IMA, 2009). The American Association of University Instructors was formed in 1916, changing their name to the American Accounting Association (AAA) in 1936 (AAA, 2009). More recently, The Association of Certified Fraud Examiners was founded in 1988 (ACFE, 2009).

According to Putnam (2000), membership in professional organizations began to decline in the 1970's, after doubling in size from 1945 to 1965 (ibid. pp. 83-84). At first, these declines were not recognized by the organizations because the rate of decline was hidden by the large influx of people into these professions after 1970 (ibid., p. 84). When the rate of declines were discovered, organizations attributed it to outdated programs, high dues, or movement to organizations more local or specialized (ibid., p. 85). Putnam notes that one of the last organizations to see a decline was the AICPA whose membership peaked in 1993 (ibid. p. 84). Most likely, membership continued to grow for the AICPA because of the increased demand for accountants, expansion of professional services and the growing number of women entering public accounting after 1970 .

While, according to Putnam (ibid., pp. 85-88), some suggest that such declines occurred because social interactions developed at the work place, Putnam argues that such interactions may have been hindered by changes in the workplace due to downsizing, increased use of contingent workers and other economic disruptions (ibid., pp. 85-88).

People often cite reasons such as increased time commitments at work or home and financial distress associated with those economic disruptions mentioned above for not joining professional organizations. Putnam notes that there is some evidence to support "modest" declines in relation to such pressures. (ibid., p. 203). Accounting educators may also be choosing not to join professional organizations because their colleges or universities are not encouraging them to do so, or do not view such memberships as important. Even at the high school level, membership in professional organizations may not be given much importance. In a 
survey of school counselors, many responses indicated a "concern" about "the lack of value attributed to professional membership by schools and school districts" (Bauman, 2008, p. 175).

While there are indications of declines or relatively flat trends in professional accounting organization memberships over the years, interest for this paper was focused on finding out how accounting educators viewed membership and what factors may have influenced their decision not to join. Below the methodology for the research and results are discussed.

\section{METHODOLOGY}

Accounting educators from colleges and universities in New York State, offering a bachelor's degree or higher, were solicited to participate in an online survey. In total, 447 accounting educators were contacted by e-mail. Most names were obtained from the Accounting Faculty Handbook (Hasselback, 2008). All survey responses were completely anonymous and anyone could exit the survey at anytime if they chose not to complete it. While most of the questions were general in nature, some focused specifically on membership in the NYSSCPA for the following reasons:

- It is the primary professional organization for CPAs in New York.

- It has local chapters available for membership

- It has a large continuing education organization - The Foundation of Accounting Education

\section{Results AND Discussion}

\section{Biographical Data}

A total of 75 educators $(16.78 \%)$ responded to the survey. Table 1 presents biographical data on the respondents. The data show that most 
of the respondents were experienced instructors with prior real-world experience.

Nearly all of the respondents were at academic rank of assistant professor or higher with nearly $30 \%$ at the professor rank. Over twothirds had achieved tenure status. Almost two-thirds held a Ph.D. (or DBA) and over two-thirds were CPAs. Other certifications mentioned were the CMA and CFE. It was expected that a large number of accounting instructors would have a public accounting background. Data shows that over $60 \%$ had public accounting experience prior to entering academia. About $18 \%$ had a management accounting background. Legal and high school teaching made up the "Other" category. In addition, over $77 \%$ of the respondents were from AACSB accredited programs.

\section{Professional Organization Membership}

Table 2 presents responses related to membership in the NYSSCPA and other professional organizations.

In relation to NYSSCPA membership, only about $40 \%$ indicated they were members. Thus, less than half of the respondents are currently members. In relation to membership in other organizations, less than half indicated membership in the AICPA with lower percentages indicted for other professional organizations. The most commonly cited reasons for nonmembership in the NYSSCPA are the cost of dues and that the organization does not meet the educator's needs. Somewhat surprising was that only $25 \%$ of non-members indicated that time constraints were a factor. Generally, it is often assumed that many do not participate in these organizations because they are too busy at work and with family commitments.

When both members and nonmembers were asked about their awareness of the benefits of membership in the NYSSCPA, almost all knew of The CPA fournal. Fewer were familiar with other benefits such as The Trusted Professional, local chapters and local chapter CPE. Only $60 \%$ 
of respondents were aware of the NYSSCPA website which displays a great deal of information regarding the organization and issues facing the accounting profession. The website not only shows upcoming events, including CPE sessions and information on local chapters, it provides access to publications such as The CPA fournal and The Trusted Professional. Other accounting organizations discussed in this paper also have web sites to encourage both members and non-members to become acquainted with its organization.

While $65 \%$ of respondents indicated awareness of the FAE and local chapter $\mathrm{CPE}$, only $35 \%$ indicated using the NYSSCPA for CPE. This may be due to the fact that some educators obtain most of their $\mathrm{CPE}$ from academic conferences and self-study alternatives. Also, some educators may not be registered CPAs and thus do not need CPE; however, with teaching coming under the scope of practice under the proposed new accountancy reform law in New York, this may change.

In response to satisfaction with current benefits of the NYSSCPA, $90 \%$ of members indicated they were satisfied with the current benefits. The organization appears to be meeting the needs of these respondents. Nonmembers appear to be most concerned over the high cost of dues and that the organization does not really meet their needs. While dues are adjusted for length of time as a CPA, there is no reduction in dues for academics (NYSSCPA, 2009).

\section{Opinions About Professional Organization Memberships}

Respondents were asked a series of statements about professional organization and professional organization membership. A 5-point Likert Scale was used with "1"indicating "Strongly Disagree" and " 5 " indicating "Strongly Agree." Table 3 presents the results.

Respondents agreed that:

- Belonging to a professional organization is important for accounting educators 
- Belonging to a professional organization enhances the opportunity to interact with accounting professionals

- Accounting educators should be actively involved in a professional organization (e.g., serve on boards, committees, etc.)

- Being an active member of a professional organization provides a good role model for students

They were neutral on the following questions:

- The benefits of membership in a professional organization outweigh the cost.

- Professional organizations such as the AICPA and the NYSSCPA have lost their significance to accounting educators.

- Accounting educators are better served belonging to a professional organization such as the American Accounting Association

Next, the opinions were analyzed by academic rank, degree held, holds CPA license, and years in education to observe any differences from the overall results. Table 4 below shows the responses by academic rank. It should be noted that responses for the Lecture/Instructor category are very low. The results indicate that there is general agreement about belonging to a professional organization, opportunities to interact with accounting professionals, benefits of membership with a more neutral position taken by Assistant and Associate ranks, being an active member but more strongly supported by Professors. There was disagreement among ranks as to whether professional organizations had lost their significance to accounting educators. Instructor/Lecture and Assistant ranks tended to disagree, Associate and Professor ranks tended to be neutral. As to be better served by educator organizations such as the American Accounting Association Instructor/Lecture and Associate ranks were neutral while Assistants and Professors tended to agree. It is interesting that Associate ranks would tend to be neutral.

Table 5 examines the responses based on degree held. The results were very similar to rank. It is somewhat surprising that those with Master's 
degree were more neutral about benefits to belonging and active involvement. It would be expected they would tend to agree more since this group often associates itself with practice to a greater extent than academic research.

Table 6 looks at the responses for those holding the CPA license and those they do not. Interestingly, those not holding a CPA license tended to agree more with belonging to a professional organization, benefits of membership over cost, and active involvement and slightly disagreeing with the loss of significance of professional organizations.

Table 7 examines the responses based on years in education. It was grouped into four categories. Low responses were found in the earlier years. Again, a downward trend can be seen in the responses of belonging and interaction. Those in the beginning years, tended to be neutral as to being actively involved. Perhaps this is due to the fact that they may be concentrating on achieving tenure and do not consider this to be as important at that time.

Overall results (Table 3) seems to indicate that accounting educators feel that professional organizations are important, but are undecided about benefits outweighing the cost. Another potentially troublesome finding for professional organizations is that, even though educators agree that such organizations are important, they are "on the fence" as to the significance of these organizations to them. However, when broken down by different categories, differences were found. The good news is that even over different categories, educators tend to feel professional organizations are important to them and their students.

The manner in which professional organizations respond to accounting educators in the future may determine the positive or negative direction educators will take. Professional organizations should look at the trend of membership in relation to educators. Perhaps the trend is upward because of changes in the CPA licensing rules and scope of practice in New York State. Professional organizations may also want 
to consider a special networking event for educators to learn more about the organization and benefits. Every Chapter of the NYSSCPA has an Outstanding Accounting Student Award Night event with a formal dinner and guest speakers. Attendance by practitioners has been extremely low even though the Chapter has made efforts to select guest speakers and topics of interest to practitioners. Some firms do send a representative to support the award winner. Also, the number of educators who come is low as well. Perhaps a networking event involving only practitioners and educators would be more appealing. Or perhaps Putnam is correct that we no longer care about participating in these types of events and the impact of social media has increased the trend.

Somewhat surprising is the neutrality regarding organizations that are focused almost exclusively on educators. It would seem that educators would agree that such organizations are better at addressing educators' needs. This is a potentially troublesome finding for such organizations as the American Accounting Association.

\section{SUMMARY}

A survey was conducted to obtain the views of accounting educators in New York State from institutions offering a bachelor's degree and higher regarding membership in professional organizations. Results showed that educators generally agreed that belonging to and participating in professional organizations was important. They were neutral about benefits exceeding the costs of belonging to a professional organization and that these organizations have lost their significance to accounting educators. When the opinions about professional organizations were analyzed by the categories of academic rank, degree held, and CPA license held' some differences were noted. However, the results should show that educators feel belonging to a professional organization is important and provides opportunities for interaction with practitioners are important. Data also indicate that cost of dues and not 
meeting the educator's needs were the most selected reasons for not being a member of the NYSSCPA.

Based on the survey results showing low membership but acknowledgement of the importance of professional organization, these organizations should be encouraged to increase contact with educators to provide information about the advantages of membership. All the organizations included in this paper have outreach and opportunities for educators. For several years, the AICPA has held a national Accounting Educators Conference. The NYSSCPA Higher Education Committee has held the NYS Accounting Educator's Conference since 2006. This year's conference will be held in April 2011 in New York City. The FEI has recently initiated an invitation to educators to join its "Academic membership" program. The ACFE also has an extensive program for educators.

Several limitations of the study prevent generalization of the results. First, the response rate $(16.78 \%)$ is low. Secondly, the pool of subjects were all from New York State schools and only from schools offering a bachelor's degree or higher. Lastly, although formal response bias analysis was not done because all responses were anonymous, there may be some bias in that the majority of respondents were long-time educators, held a CPA license, and were from AACSB accredited schools.

Future research directions include expanding the research to two-year schools, investigating indicators of non-membership such as the cost of dues, and determining how professional organizations can better meet the needs of accounting educators.

\section{REFERENCES}

American Accounting Association (AAA). 2009. Date of origin. Sarasota, FL. Available at: http://aaahq.org/about.cfm 
Association of Certified Fraud Examiners (ACFE). 2009. Date of origin. Austin, TX. Available at:

http://acfe.com/resources/view.asp?ArticleID $=811$

Bauman, S. 2008. To Join or Not to Join: School Counselors as a Case Study in Professional Membership. Journal of Counseling and Development 86: 164-177. http://dx.doi.org/10.1002/j.1556-6678.2008.tb00494.x

Carpenter, C. and E.F. Stephenson. 2006. The 150-Hour Rule as a Barrier to Entering Public Accountancy. Fournal of Labor Research XXVII (1): 115-126. http://dx.doi.org/10.1007/s12122-006-1013-0

Devonsh-Mills, L. 2008. Strategic Plan Update. Strategic Finance (August): 21

Financial Executives International (FEI). www.financialexecutives.org

Hasselback, J. 2008. Accounting Faculty Directory 2008-2009. Upper Saddle River, N.J., Pearson Education, Inc.

Institute of Management Accountants (IMA). 2009. Date of Origin. Montvale, N.J. Available at: http://imanet.org/pdf/about IMA full presentation may2008_mg edits (3).pdf

Institute of Internal Auditors (IIA). 2009. Date of Origin. Altamonte Springs, FL. Available at: http://www.theiia.org/theiia/about-theinstitute/

King, G. and T. Sutherland. The AAA Commons: The Latest Benefit of AAA Membership. Accounting Education News (Fall 2008): 4-5.

Merriam-Webster's Collegiate Dictionary, $10^{\text {th }}$ ed., (2001), s. v. "profession."

Merriam-Webster's Collegiate Dictionary, $10^{\text {th }}$ ed., (2001), s. v. "professional."

McWeeney, Jr., J.E. 2008. A Member Driven Organization. New fersey Banker (Fall): 8-12.

New York State Society of Certified Public Accountants (NYSSCPA). 2009. Date of Origin. New York, N.Y. Available at: http://www.nysscpa. org/page/about-us/society-overview 
24 BRC Journal of Advances in Business Vol. 2, No. 1 .2009. Information on dues. New York,

N.Y. Available at:

(http://www.nysscpa.org/society/dues.htm

Putnam, R.D. 2000. Bowling Alone: The Collapse and Revival of American Community. New York, N.Y., Simon \& Schuster.

Scarborough, M. 2008. The Value of Belong. Community Banker (May): 30.

Schea, F.E. (2009). Preparing for Downsizing. Strategic Finance (January): 6.

Previts, G. and B. Merino. 1998. A History of Accountancy in the United States: The Cultural Significance of Accounting. $2^{\text {nd }}$. ed. Columbus, $\mathrm{OH}$. Ohio State University Press.

\section{Web Appendix}

A web appendix for this paper is available at:

http://dx.doi.org/10.15239/j.brcadvjb.2014.02.01.wa02

\section{Citation Information}

Kent, Donald D., Jr., Phyllis Bloom, and Susan L. Murphy. "An Investigation of Professors' Views on Membership in Professional Organizations." BRC Fournal of Advances in Business 2, no. 1 (2014): 13-24. http:// dx.doi.org/10.15239/j.brcadvjb.2014.02.01.ja02 